\title{
Corrigenda: Polyphyly of the traditional family Flabellinidae affects a major group of Nudibranchia: aeolidacean taxonomic reassessment with descriptions of several new families, genera, and species (Mollusca, Gastropoda). https://doi.org//0.3897/zookeys.717.21885
}

\author{
Tatiana Korshunova ${ }^{1,2}$, Alexander Martynov², Torkild Bakken ${ }^{3}$, Jussi Evertsen ${ }^{3}$, \\ Karin Fletcher ${ }^{4}$, I Wayan Mudianta ${ }^{5}$, Hiroshi Saito ${ }^{6}$, Kennet Lundin ${ }^{7,8}$, \\ Michael Schrödl ${ }^{9,10}$, Bernard Picton ${ }^{11,12}$
}

I Koltzov Institute of Developmental Biology, RAS, 26 Vavilova Str., 119334 Moscow, Russia 2 Zoological Museum, Moscow State University, Bolshaya Nikitskaya Str. 6, 125009 Moscow, Russia 3 NTNU University Museum, Norwegian University of Science and Technology, NO-7491 Trondheim, Norway 4 Port Orchard, Washington 98366, USA 5 Universitas Pendidikan Ganesha, Bali, 81116, Indonesia 6 National Museum of Nature and Science, Amakubo 4-1-1, Tsukuba, Japan 7 Gothenburg Natural History Museum, Box 7283, S-40235, Gothenburg, Sweden 8 Gothenburg Global Biodiversity Centre, Box 461, S-40530, Gothenburg, Sweden 9 Zoologische Staatssammlung München, Münchhausenstr. 21, D-81247 Munich, Germany 10 Biozentrum Ludwig Maximilians University and GeoBio-Center LMU Munich, Germany II National Museums Northern Ireland, Holywood, Northern Ireland, United Kingdom 12 Queen's University, Belfast, Northern Ireland, United Kingdom

Corresponding author: Alexander Martynov (martynov@zmmu.msu.ru)

Academic editor: N. Yonow | Received 14December 2017 | Accepted 19 December 2017 | Published 29 December 2017

http://zoobank.org/0A02E6D3-970D-45D7-AB36-1E6A31B81CCD

Citation: Korshunova T, Martynov A, Bakken T, Evertsen J, Fletcher K, Mudianta IW, Saito H, Lundin K, Schröd M, Picton B (2017) Corrigenda: Polyphyly of the traditional family Flabellinidae affects a major group of Nudibranchia: aeolidacean taxonomic reassessment with descriptions of several new families, genera, and species (Mollusca, Gastropoda). https://doi.org/10.3897/zookeys.717.21885. ZooKeys 725: 139-141. https://doi. org/10.3897/zookeys.725.23022

In our recently published study the traditional Flabellinidae underwent a major revision and 17 new genera were proposed. The Abstract should read " 17 new genera".

Immediately after publication our attention was drawn to homonymy of three generic names: Borealia, Occidentella, and Orientella with Borealia Maksimova, 1977, an extinct trilobite, Occidentella Hoffmann, 1929, a junior synonym of Onchidella, a pulmonate slug, and Orientella Repina \& Okuneva, 1969, another extinct trilobite. In Copyright Tatiana Korshunova et al. This is an open access article distributed under the terms of the Creative Commons Attribution License (CC BY 4.0), which permits unrestricted use, distribution, and reproduction in any medium, provided the original author and source are credited. 
a stroke of irony the two trilobite names were published in little known Russian journals, with Russian descriptions. To avoid homonymy, throughout the text, figures, and all supplementary materials replacement names for these three genera are as follows: Borealea Korshunova et al., nom. n., Occidenthella Korshunova et al., nom. n., and Orienthella Korshunova et al., nom. n. We are grateful to Jimmy Gaudin for alerting us to this unfortunate circumstance. Other corrections are as follows:

On p. 14 "...the same region our..." should be "...the same region as our..."

On p. 16 "...additional rows of of small..." should be "...additional rows of small..."

On p. 17 In the diagnosis of Paracoryphella ignicrystalla should be "... rachidian tooth with up to 15 denticles..."

On p. 18 "...cusp of nealy $1 / 3$ of the tooth..." should be "...cusp of nearly $1 / 3$ of the tooth..."

On p. 19 "... Coryphella polaris Voldochenko, 1946...” should be “...Coryphella polaris Volodchenko, 1946..."; “...(Figs 7, 10H, I)...” should be “...(Figs 7, 11H, I)...”; “...(Fig. 10G) ..." should be “...(Fig. 11G)..."

On p. 26 Table 1. In fifth column: minimum uncorrected p-distances between Coryphella verrucosa and Itaxia falklandica should be $17.2 \%$.

On p. 27 "...original description in Verril, 1880..." should be “...original description in Verrill, $1880 \ldots$..”; “...detailed redescripton in Kuzirian...” should be “... detailed redescription in Kuzirian...”

On p. 31 In the diagnosis of Fjordia chriskangei should be "...orange-brown to reddish brown, sometimes blackish..."

On p. 33 In the diagnosis of Fjordia lineata should be: “...orange-brown to salmon, bright red, and dark brown, sometimes almost black..."

On p. 35 In the diagnosis of Gulenia monicae should be "...delineated from central cusp..."

On p. 37 In the diagnosis of Gulenia orjani should be "...delineated from central cusp..."

On p. 52 "...inclusion of F. funeka and $F$. ishitana is not..." should be "...inclusion of F. funeka and F. ischitana is not..."; "... and "Piseinotecus" gabienerei must be..." should be "... and "Piseinotecus" gabinierei must be..."

On p. 53 "... related to Paraflabellina ishitana..." should be "... related to Paraflabellina ischitana..."

On p. 54 "... (pleuroproctic in higher acleiproctic position)..." should be “...(pleuroproctic in higher acleioproctic position)..."

On p. 57 "...on distinct elonagate elevations..." should be “...on distinct elongate elevations..."; “... (pleuroproctic in higher cleiproctic position)...” should be “... (pleuroproctic in higher acleioproctic position)..."

On p. 58 In the diagnosis of $U$. nihonrossija should be "....apical parts of cerata without white pigment... rachidian tooth with up to seven denticles, central cusp without small denticles, double proximal receptaculum seminis...".

On p. 66 "...due to the lack of the morphlogical description..." should be "...due to the lack of a morphological description..." 
On p. 68 "...always posses oral glands..." should be "...always possess oral glands..." On p. 74 "... reduction of the triserial radula into a unserial one..." should be "reduction of the triserial radula into a uniserial one..."

On p. 79 Figure 3. Should be Chlamylla borealis borealis Bergh, 1886

On p. 91 "(Cothouy, 1839)" should be "(Couthouy, 1838)"

Supplementary material 2. Chlamylla atypica should read Chlamylla borealis borealis Bergh, 1886. Localities for Himatina trophina (Bergh, 1890) GQ292023 and Microchlamylla amabilis (Hirano \& Kuzirian, 1991) GQ292022 should be "WA, USA".

\section{References}

Hoffman H (1929) Zur Kenntnis der Oncidiien (Gastrop. pulmon.) Ein Beitragzur geographischen Verbreitung, Phylogenie und Systematik dieser Familie. Zoologische Jahrbücher Abteilung für Systematik, Ökologie und Geographie der Tiere, Jena 57: 253-302.

Maksimova ZA (1977) Devonian trilobites from Novaya Zemlya and other regions of Soviet Arctica. Ezhegodnik vsesoyuznogo paleontologicheskogo obshestva [Yearbook of paleontological society of USSR] 20: 140-190. [In Russian]

Korshunova TA, Martynov AV, Bakken T, Evertsen J, Fletcher K, Mudianta W, Saito H, Lundin K, Schrödl M, Picton B (2017) Polyphyly of the traditional family Flabellinidae affects a major group of Nudibranchia: aeolidacean taxonomic reassessment with descriptions of several new families, genera, and species (Mollusca, Gastropoda). ZooKeys 717: 1-139. https://doi.org/10.3897/zookeys.717.21885

Repina LN, Okuneva OG (1969) Cambrian arthropods of Primorie. Paleontologichesky Zhurnal [Paleontological Journal] 1: 106-114. [In Russian] 